\title{
The Economic Goal of Library Automation
}

A steadily increasing rate of productivity should be the economic goal of library automation. Such productivity will be achieved only by development of a new library technology. Thereby, rise in library costs, which are going up exponentially at a frightening rate, will be brought into line with cost rises in the economy as a whole.

A CADEMIC LIBRARIES are in crisis, and it appears that the larger the library, the larger the crisis. The major need for charting a course to a successful future is definition of fruitful objectives. Such objectives as library support of and coordination with its institution's programs are no longer sufficient; these rationalized goals of the past are inadequate for the future. To establish useful system objectives, much research must be done to determine needs of students and faculty. ${ }^{1}$ For instance, it has been customary for academic librarians to speak of faculty library use as though each faculty member has basically the same needs, but a recent Harvard report reveals that 65.7 per cent of the Harvard tenured faculty does not feel that the Harvard libraries are one of three most attractive or three least attractive features of the Harvard environment. ${ }^{2}$ Can it be that for two-thirds of the Harvard faculty the quality of the countyy's largest university library system does not differ significantly from that of other institutions?

1 A. Graham Mackenzie, "Systems Analysis of a University Library," Program; News of Computers in British Libraries, II (April 1968), 7-14.

${ }^{2}$ Harvard University. Faculty of Arts and Sciences. Report of the Committee on Recruitment and Retention of Faculty (Cambridge: Harvard University, 1968), p. 69.

Mr. Kilgour is Director in Ohio College Library Center, Columbus, Ohio.
Although the crisis in which academic libraries find themselves is typically of library character, there is one portion which they share with their institutions, namely, "the massive financial crisis that threatens a major sector of the nation's institutions of higher education," as a recent AAUP report has put it. ${ }^{3}$ The following exposition will define an economic goal-in contrast to a system objective-of library computerization that when attained will relieve libraries of their financial plight.

\section{The Financial Crisis}

William G. Bowen has recently depicted and skillfully analyzed the financial problem of institutions of higher education with emphasis on private universities. ${ }^{4} \mathrm{He}$ found that private universities experienced an annual rise in cost per student of 7.5 per cent, and he emphasized the fact that much of his analysis "applies, in varying degrees, to public as well as private institutions, and to colleges as well as universities." This compound rate of increase at 7.5 per cent per annum compares with a 2 per cent increase in the general economy.

${ }^{3}$ William Baumol and Peggy Heim, "On the Financial Prospects for Higher Education: The Annual Report on the Economic Status of the Profession, 196768," AAUP Bulletin, LIV (June 1968), 182-241.

4William G. Bowen, The Economics of the Major Private Universities (Berkeley, California: The Carnegie Commission on the Future of Higher Education, 1968). 


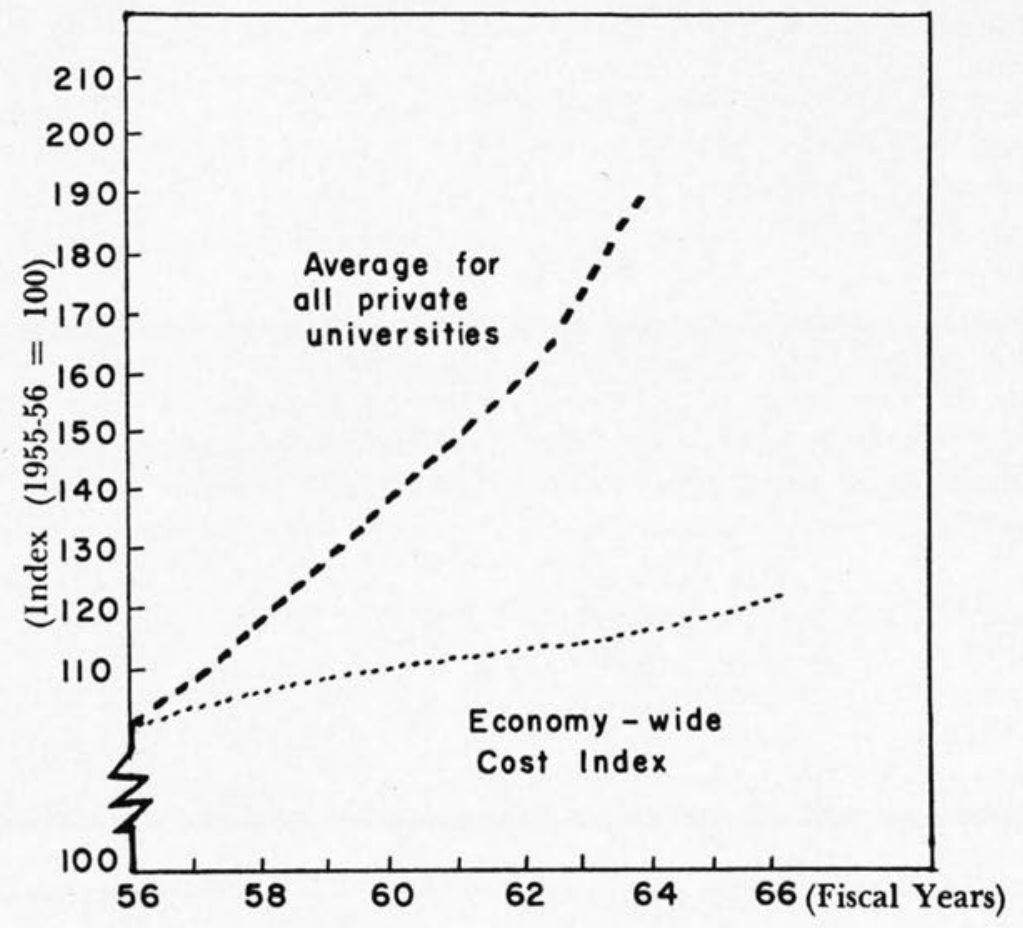

FIGURE 1

\section{Direct Costs Per Student in Private Universities, Compared with an Economy-wide Cost Index, 1955-56 to $1965-66$}

(Courtesy AAUP Bulletin)

Bowen ascribes a higher rate of cost rises in higher education to the fact that the technology of education has not increased productivity of educators. In the general economy output per man hour of labor input has been rising steadily at approximately 2.5 per cent per year, in contradistinction to essentially no rise in productivity in higher education. Still, rising salaries and higher standards of living that reflect increased productivity have forced up salaries of educators.

Although there are varying views on effectiveness of an innovative technology of education to increase productivity of educators, most authorities feel that there will be no significant increase in productivity in the foreseeable future.
Bowen estimates that in a "typical" major private university, expenditures per student will rise from $\$ 3,500$ in $1965-66$ to $\$ 7,210$ in $1975-76$; during the same decade total educational and general expenditures for the institution will rise from $\$ 24,500,000$ to $\$ 70,658,000$. He comments, "These projected increases are not just large-they are staggering, by almost anyone's definition of that word." Baumol and Heim have estimated that if the rate of increase of cost per student at private institutions continues unchanged for the next forty years, it will rise to nearly sixteen times above the present level..$^{5}$

It would appear that bankruptcy ${ }^{5} \mathrm{Op}$. cit. (Reference 3), p. 184. 
would occur before costs could rise to such overwhelming heights. Certainly presidents and boards of trustees would avert financial bankruptcy, but in so doing, they would just as certainly bankrupt their educational and research programs. Indeed, there is some evidence that academic libraries may already have begun to fail to meet their obligations, for in the five-year period from $1960-61$ to $1965-66$, the number of volumes per student in American college and university libraries declined from 52.4 to $45.8 .^{6}$

Although Bowen is pessimistic about the realization of cost benefits from innovative educational technology, he points out that there is one area that justifies optimism-the library. He cautions, however, that "savings will be realized only after there have been considerable expenditures on experimental efforts, equipment, retraining of staff, and so on."

\section{TeChNOLOGY AND LibRaRIES}

The largest and most expensive machines in libraries are heating systems, air-conditioning systems, and elevators, and none of these machines can be said to be "innovative technology." An innovative technology is a technological system which is continually being developed. An edge-notched punch card system is not an innovative technology; such a system does not experience development on a technological level. Introduction of an edge-notched punched card system will effect a one-step increase in productivity, but it does not possess the potential for continual development accompanied by continual increase in productivity. Similarly, column punch cards with unit record machines were not an innovative technology; the present-day sorter is basically the same machine doing the same task, albeit

The Bowker Annual, 1968 (New York: R. R. Bowker Co., 1968), p. 42. faster, that Hollerith's first sorter did in 1886. Computer technology is a wholly new and truly innovative technology that superseded, but did not evolve from, unit record equipment much in the manner that printing superseded the scribe. An innovative technology that steadily increases productivity of librarians cannot be said to exist. Indeed, library operating costs per student rose at an annual average of just over 5 per cent from 1959-60 to 1965-66. ${ }^{7}$

The technique of descriptive cataloging in the twentieth century does not differ in any essential way from that done during the Middle Ages, except that there is a great deal more of it. To be sure, the twentieth-century cataloger conforms to more complicated rules, and the typewriter has replaced the ink pen.

In contradistinction to the lack of innovative technology in the production of catalog entries is the technology that has immensely increased the productivity of those reproducing the entries. Little is known of the rate of work of scribes, but an example of rapid work is the production of a ninth-century manuscript containing 109 ten-by-eight-inch leaves, having twenty lines per page. Two scribes produced this work at the rate of fifteen pages per day per scribe. ${ }^{8} \mathrm{Mi}$ chael Clapham has expressed the view that the first half century of printing from movable type produced more books probably than all European scribes had produced in the previous millenium. ${ }^{9}$ In the nineteenth century, the introduction of the power press and typecomposing machines further enhanced productivity. In 1857, a power, rotary Hoe newspaper press could produce 20,000 impressions an hour, but required twenty-five men and boys to operate

\footnotetext{
Ibid., p. 43.

${ }^{8}$ Florence Edler De Roover, "The Scriptorium," in James Westfall Thompson, The Medieval Library (New York: Hafner Publishing Co., 1965), p. 607. "Michael Clapham, "Printing," in Charles Singer, et al., eds. A History of Technology (New York: Oxford University Press, 1957) III, 377-411.
} 
it. ${ }^{10}$ Today, widely used power presses can produce 20,000 impressions an hour, each containing sixteen pages with twice as many lines as those produced by the scribes mentioned above. Such a press requires three men to operate and a larger group to compose the text from which printing is accomplished. If it is assumed that twenty men in all are involved full time in composing and printing on such a press, their productivity is approximately two thousand times greater than that of the fast-writing scribes of the ninth century. In recent years the printing and publishing industry has enjoyed an annual growth in productivity of 2.7 per cent, ${ }^{11}$ an achievement which doubly exacerbates the library crisis.

\section{Productivity}

Basing his exposition on the work of Solomon Fabricant, George Soule describes changes in productivity as coming from: (1) changes in technology, economic organization, and management skills; (2) changes in quality and aptitude of the worker; and (3) changes in machinery or equipment supplied the worker. ${ }^{12}$ Of these various ingredients technological innovation is certainly the most important, although technological innovation by itself cannot achieve increased productivity.

Output per man hour of labor input is the generally accepted measure of productivity. To increase productivity in libraries, librarians must employ an innovative technology that has the potential for dynamically increasing productivity at an essentially steady percentage rate at least equal to the rate of increases in costs. The only technology which can achieve these goals is computerization with its attendant facets, particularly comprehensive system design.

${ }^{10} \mathrm{~W}$. T. Berry, "Printing and Related Trades," in ibid., $V$, 683-715.

"Clopper Almon, The American Economy to 1975 (New York: Harper \& Row, 1966), p. 126.

${ }^{12}$ George Soule, The New Science of Economics, an Introduction (New York: Viking, 1964), p. 142.
Since the 1920s, librarians have applied techniques of scientific management with varying degrees of enthusiasm and success with the hope of reducing costs. After a third of a century, however, per-student costs are rising about twice as rapidly as unit costs in general. Fundamental to the concept of scientific management is the establishment of a level of productivity to be expected from an incumbent in a particular job; in effect, a ceiling of productivity is set for a worker. Only if such ceilings were to exist throughout the entire economy could scientific management alone effect a real, if limited, reduction in costs. Introduction of an innovative technology into libraries will remove static ceilings, although it should not be forgotten that techniques of scientific management can continue to improve efficiency in a milieu of increasing rates of productivity.

It is well known that the preparation of volumes for the shelves incurs a significant percentage of total library operating expenditure, and it appears that the larger the library the higher the unit cost. ${ }^{13}$ Clearly a fruitful area for effective increase in productivity is in cataloging operations. However, computerization of the reproduction of nineteenth-century forms of catalogs, namely, card catalogs and bookform catalogs, will not produce significant increases in productivity. What is needed is the mechanization of the cataloging process itself.

To increase productivity of cataloging operations rather than merely to improve efficiency will require mechanization of descriptive cataloging, subject classification, and subject indexing. The prospect for computerization of subject heading and subject classification activity is not particularly bright, for a major ingredient, efficient machine transla-

${ }^{13}$ Catherine MacQuarrie, "Cost Survey: Cost of Ordering, Cataloging, and Preparations in Southern California Libraries," Library Resources \& Technical Services, VI (Fall 1962), 337-350. 
tion, is lacking, and its successful development does not appear to be imminent. However, major strides in mechanization of descriptive cataloging can be taken in the immediate future. Some years ahead lies the ultimate goal of mechanically reading the title page of a book into a file organized so that the user can retrieve the reference more readily than from a bookform or card catalog. Two principal innovative components are required for an activation of mechanized descriptive cataloging. One is a logical file organization in which to store text on a title page and from which the text can be retrieved rapidly and efficiently. The second is a mechanical device for reading title pages and converting characters thereon to digital form in a computer. It now appears that the first-mentioned development will precede the second, but prior to the development of efficient optical character recognition title pages can be transposed manually as has been done for centuries.

Because of such great potential for increasing productivity in library operations as this example of the mechanization of the catalog reveals, it is most desirable that any library computerization project should be an initial step in the direction of increased productivity and not solely an improvement in efficiency of an isolated procedure. To assure that computerization moves in a desirable direction, it will be necessary first to model the desired future system. ${ }^{14,15}$ For

14 Richard DeGennaro, "The Development and Administration of Automated Systems in Academic Libraries, "Journal of Library Automation, I (March 1968), 75-91.

${ }^{15}$ Frederick G. Kilgour, "Systems Concepts and Libraries," College \& Research Libraries, XXVIII (May 1967), 167-170. instance, an on-line file of catalog records should not mimic a card catalog, but rather should be organized in such a way as to facilitate future mechanical descriptive cataloging.

Much education, research, and development will be required to produce and operate library systems that will possess the characteristic of increasing productivity. Education will be required for users, staff, and management. There will also be the need for varying degrees of internal and external library reorganization; it seems most likely that it will be necessary to develop formal federations, or networks, of libraries to enable the vast majority of libraries to participate in computerization. Although libraries are accustomed to investing large amounts of money in buildings and in book holdings, it has not been customary to invest large sums in machines. Undoubtedly such investments will occur in the future, and may very well involve libraries in heretofore little-used practices, such as large, long-term bank loans.

\section{Conclusion}

The electronic digital computer constitutes for libraries an innovative technology that will enable libraries to increase productivity of staff and thereby decelerate the exponentiality of rise in costs and eventually to bring cost rises into line with those in the economy as a whole. To activate such a program it will be necessary to adopt the goal of increased productivity; an effective route out of the burgeoning financial crisis will be along the path of increasing productivity. 